\title{
THE PERCEIVED LEVEL OF COMPETENCE BASED ON EXPERIENCE AND GENDER OF THE ADMINISTRATIVE STAFF OF PRIMARY EDUCATION IN GREECE AND THE NEED FOR TRAINING
}

\author{
ADAMOS ANASTASIOU
}

\author{
Adjunct Professor, Hellenic Open University, Patras, Greece \\ Email:adamosana@gmail.com
}

Received: 28 November 2020, Revised and Accepted: 2 January 2021

\begin{abstract}
The ideas of 'competence' and 'competencies' have become central in the last decades in education, as experts have focused their interest on the importance of setting learning objectives in order to help students familiarise themselves with the learning process. In the present study, it is examined whether there is a difference in the perceptions of the administrative staff (both principals and vice-principals) on their level of competence as far as their experience (experienced or novice - inexperienced) and a common personal characteristic, such as their gender (male or female), are concerned. A total of 412 administrative staff that is 261 principals 151 vice-principals responded to a five-point Likert-scale questionnaire. The statistical comparison was performed by applying the 2 -factor analysis of variation (ANOVA). This analysis was preceded by check for equality of variance between the respective groups (Levene's test). Based on the findings concerning experience and gender correlation, it is revealed that the greatest need for training seems to concern novice female primary school administrative staff, while on the contrary, the least need for training concerns the experienced male ones. Training programme designers should take this fact very seriously when creating educational courses.
\end{abstract}

Keywords: Administrative staff, Competence(s), Experience, Gender, Primary school.

(C) 2021 The Authors. Published by Innovare Academic Sciences Pvt Ltd. This is an open access article under the CC BY license (https://creativecommons.org/licenses/by/4.0/) DOI: https://dx.doi.org/10.22159/ijoe.2021v9i1.40691. Journal homepage: https://innovareacademics.in/iournals/index.php/ijoe

\section{INTRODUCTION}

The terms' competence' and 'competency' are often confused (Winterton \& Winterton, 1999). The term 'competence' is an idea used extensively in the UK. In contrast, the term 'competency' is an idea that is heavily influenced by American thought, mainly through the work of psychologist David McClelland. We simply assume that 'competencies' are related to the outputs to specific minimum standards, while 'competencies' are related to the inputs that an individual brings to a job, which lead to maximum performance. In everyday use in the UK, the word 'competence' is used more than the word 'competency,' although many people use these two terms alternately (Davies \& Ellison, 1997).

According to Nolan and McConnell, these terms require definition, as they are often used interchangeably and may be unique but related entities. "Competence is often defined as the ability to perform, which is based on knowledge, while competency is the actual performance" (Zuzelo, 2010, p. 92). "Competencies describe what people need to do to perform well in their work, while competencies identify the dimensions of behaviour behind adequate performance" (Derek, 2013, p. 216; Foot \& Hook, 2008, p. 251). As far as the field of education is concerned, the ideas of competence and competencies have become central in the last four decades, as experts have emphasised the importance of setting learning objectives to guide curriculum designers and courses creators in order to help students to understand the learning process (Petroselli, 2008). Taking into consideration all the above, it is reasonable, from this point onwards, to illustrate that the term competence and its plural competencies will be used when referring to 'competences' 'competencies,' 'competence' and or 'competency.'

Various surveys have been conducted concerning the perceived level of competence, but none of them examines whether they are related or differentiated according to the experience of administrative staff and some of their common personal characteristics (such as gender, position and titles in business administration) or characteristics concerning the general environment - situation (such as the number of school classes and the population of the area of the district where the schoo is located), to determine whether these factors affect their effectiveness. Therefore, it is highly interesting to consider whether there is a difference in the perceptions on the level of competence of the administrative staff as far as their experience (experienced or inexperienced) and a personal characteristic, such as their gender (male or female), are concerned.

\section{BACKGROUND OF THE STUDY}

The choice of competences is the most important process in the development of training activities for managers (Wilburn \& Summers, 1983, p. 11), whereas Roberts links competence to the early stages of the recruitment and selection process (Wilson, 2005, pp. 170-171). More generally, however, we can argue that the important benefit of the competence approach to management development focuses on what managers do and not on assumptions about what managers do (Robotham \& Jubb, 1996). The framework that follows is highly important to define competencies (Wintperton \& Winterton 1999, p. 27), as shown in the figure that follows:

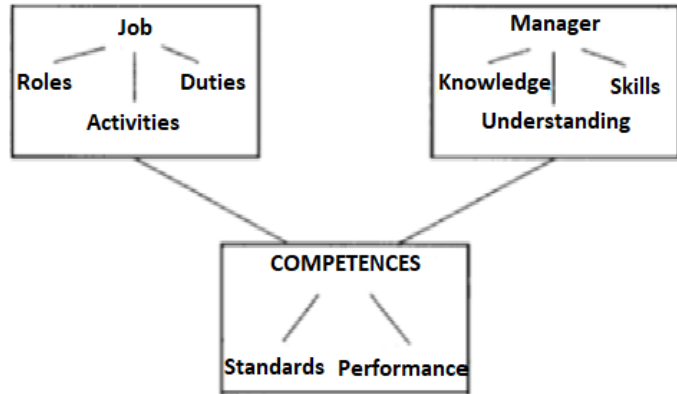

Fig. 1: A framework for competences

Human beings seek competence since everyone desires to do the right thing. The challenge and the opportunity for school leaders are to cultivate the know-how of staff and students in their work, their way of thinking and their daily actions. 
Achievement comes through competence, experience and knowledge (Deal \& Peterson, 2010). In theory, there are many views on the competencies of school leaders and more often there is an identification between them. School leader competences can be divided into two groups (Dyrda \& Pryzbylska, 2008, p. 131).

- The internal concerning the planning, the control, the management, the organisation, the duties of the employer.

- The external ones concerning the school's representation, the cooperation with other organisations, the creationbuilding of the image of the school or the institution.

The effectiveness of school leader's leadership depends on whether they can facilitate member's participation and involvement in the decision-making and planning process, the communication among the school's multiple groups, the collaboration among different school units, the social interactions and relationships among members, the development of school climate, as well as the basic teaching and learning activities (Cheng, 2005). School leadership competencies require not only to inspire teachers in their commitment towards students but also to challenge and support those who fail to improve their teaching practice (Dipaola \& Forsyth, 2011, p. 11). Essentially, the issue of competencies requires school leaders to see each individual as capable of approaching maximum performance with minimum supervision (McAndrew, 2005), directing in this way a great deal of research interest in studying competencies.

\section{SIGNIFICANCE OF THE STUDY}

Even though much research has been done based on competencies, there is a void concerning the perceptions on the level of competence of the administrative staff (both principals and vice-principals) as far as their experience and gender are concerned. Probable incompetence on their part may unfold an urgent need for training so that they can perform their task on the best effective level.

\section{OBJECTIVE}

The objective was to examine whether there is a difference in the perceptions of the administrative staff (both principals and vice-principals) on their level of competence as far as their experience and gender are concerned.

\section{HYPOTHESES}

It is speculated that the novice primary school administrative staff need more training than the experienced ones and also that male primary school administrative staff needs less training than the female ones.

\section{METHODOLOGY}

Population and area

The target population of the research was the 496 administrative staff, that is, 305 principals and 191 viceprincipals, of a total of 312 six-grade or more primary schools in the prefecture of Thessaloniki in Greece.

\section{Research Sample}

At the end of the survey, a total of 412 administrative staff (a percentage of about $83 \%$ in the whole prefecture), that is 261 principals (who constitute $52.6 \%$ of the total number of the administrative staff and $85.6 \%$ of the total number of principals of this prefecture) and $85.6 \%$ of the 151 viceprincipals (who constitute $30.4 \%$ of the total number of the administrative staff and $79.1 \%$ of the total number of viceprincipals of this prefecture), responded completing it sufficiently and in such a way that data can be used to analyse and draw conclusions about the correlation between experience and gender.

\section{Research tool}

To measure the competence of administrative staff (school principals and vice-principals), the questionnaire "Principal's
Perception of Competence Survey" of the American researcher Kelly Glodt was used, translated into Greek and adapted to the Greek reality following the process of backward translation. The questionnaire is divided into two sections. The first part includes general questions about the demographic characteristics of the respondents, while the second includes 41 five-point Likert-scale items with the following values: $1=$ fully competent, 2=somehow competent, 3=marginally competent, $4=$ not competent and $5=$ have never experienced which investigate certain competences of principals and viceprincipals concerning common administrative responsibilities of their work. Administrative staff with up to three years of experience were considered inexperienced for this study, while those with more years were considered inexperienced. This decision was made because a three-year experience was considered sufficient time for a principal or a vice-principal to deal with certain situations, specific duties and responsibilities. Furthermore, it is of crucial importance to be mentioned that the lower the value chosen by the respondent was, the higher the perceived level of his/her competence was. This decision was made in order to be safeguarded that the respondents would not complete the questionnaire taking for granted in advance that the higher the number of their responses is, the more competent they think they are.

\section{Research method}

The comparison of the participant's responses in this research in terms of their perceptions of competence was made for each question separately, taking into account the factors "EXPERIENCE" and "GENDER," as well as the possible interaction of these two factors. The statistical comparison was performed by applying the 2-factor analysis of variation (ANOVA). This analysis was preceded by check for equality of variance between the respective groups (Levene's test). Questions that violated the condition of equality of variance were excluded from the results. The significance level was set equal to $5 \%(\mathrm{p}=0.05)$. According to the factor analysis that took place, the following conclusions emerged:

1. The questions excluded from the analysis are the following: $1,6,10,11,14,21,23,26,34$ (because $\mathrm{p}<0.05$, so the condition of equal variations is not met, which is fulfilled only when: $p>$ $0.05)$.

2. The questions in which no statistically significant differences were identified are the following: 3, 4, 27, 41 .

3. The questions in which a statistically significant difference only with respect to the factor "EXPERIENCE" was found are the following: $2,5,7,8,9,12,13,17,19,20,24,29,30,31,32$, $33,35,36,37,38,39$.

4. The questions in which a statistically significant effect for both factors (separately) "GENDER" and "EXPERIENCE" were found are the following: 15, 16, 18, 22, 28.

5. In question 25, a statistically significant effect for both factors (separately) "GENDER" and "EXPERIENCE" was found, as well as their statistical interaction.

6. In question 40 , a statistically significant effect of the factor "GENDER" and a statistically significant interaction of the factors "GENDER" and "EXPERIENCE" were found.

\section{RESULTS}

This particular research aimed at determining whether there is a significant difference in the perceived level of competence of novice/beginner/inexperienced administrative staff (principals and vice-principals) compared to that of the experienced ones and separately between novice and experienced male administrative staff, as well as between novice and experienced female administrative staff from the prefecture of Thessaloniki in Greece in "Principal's Perception of Competence Survey" questionnaire. Table 1 below includes all the data of the administrative staff deriving from the "Principal's Perception of Competence Survey" questionnaire ranking from the best to the worst, based on the means scores of the perceived competence for novice male administrative staff $(\mathrm{N}=99)$. The number of respondents to this survey varies 
per question-item-competence. The averages were based on the values: $1=$ fully competent, $2=$ somehow competent,
$3=$ marginally competent, $4=$ not competent, as the answer $5=$ have never experienced was excluded from the analysis.

Table 1: Perceived competence means scores (ms) and standard deviations (sd) for novice male administrative staff (principals and vice-principals)

(up to 3 years of administrative experience)

\begin{tabular}{|c|c|c|c|c|}
\hline \multicolumn{2}{|r|}{ Question - item - competence } & $\mathbf{N}$ & MS & SD \\
\hline 27. & Effectively handling individual student discipline issues & 97 & 1.54 & 0.560 \\
\hline 34. & Working with parent organizations and/or committees & 98 & 1.56 & 0.593 \\
\hline 7. & Improving overall school climate & 98 & 1.60 & 0.670 \\
\hline 11. & Learning routine office tasks/procedures & 97 & 1.60 & 0.717 \\
\hline 12. & Preparing for and conducting effective faculty meetings & 99 & 1.61 & 0.667 \\
\hline 36. & Dealing with concerned/angry parents & 98 & 1.62 & 0.566 \\
\hline 39. & Possessing mediation skills (staff vs. staff and/or student vs. student) & 97 & 1.64 & 0.616 \\
\hline 40. & Possessing necessary technology skills & 97 & 1.64 & 0.632 \\
\hline 8. & Improving staff morale & 96 & 1.69 & 0.744 \\
\hline 37. & Developing decision-making skills & 96 & 1.71 & 0.664 \\
\hline 35. & Organising and supervising school activities/athletics & 96 & 1.73 & 0.672 \\
\hline 38. & Developing time management skills & 95 & 1.75 & 0.618 \\
\hline 28. & Interpreting and enforcing school law issues & 98 & 1.77 & 0.729 \\
\hline 31. & Developing public relations skills & 97 & 1.78 & 0.780 \\
\hline 19. & Analysing student data & 97 & 1.80 & 0.772 \\
\hline 32. & Possessing public speaking skills & 99 & 1.80 & 0.756 \\
\hline 15. & Addressing custodial staff issues & 98 & 1.81 & 0.741 \\
\hline 25. & Dealing with the building budget & 91 & 1.81 & 0.729 \\
\hline 18. & Guiding the school improvement process & 99 & 1.83 & 0.715 \\
\hline 14. & Addressing building maintenance issues & 97 & 1.84 & 0.746 \\
\hline 20. & Leading curriculum development & 96 & 1.85 & 0.754 \\
\hline 10. & Supervising staff & 97 & 1.86 & 0.736 \\
\hline 13. & Teacher union issues & 96 & 1.86 & 0.720 \\
\hline 16. & Addressing fire marshal issues & 96 & 1.86 & 0.749 \\
\hline 17. & Addressing secretarial staff issues & 88 & 1.86 & 0.819 \\
\hline 22. & Completing education reports & 94 & 1.88 & 0.914 \\
\hline 33. & Creating an effective site council & 93 & 1.91 & 0.702 \\
\hline 1. & Possessing instructional leadership skills & 97 & 1.92 & 0.514 \\
\hline 4. & Assisting teachers in creating more effective lesson plans & 96 & 1.94 & 0.792 \\
\hline 3. & Instructing teachers in effective instructional techniques & 93 & 1.99 & 0.699 \\
\hline 41. & Developing and preparing for board meeting presentations & 90 & 1.99 & 0.855 \\
\hline 6. & Creating an atmosphere of high expectations & 96 & 2.00 & 0.754 \\
\hline 23. & Handling site-based management & 94 & 2.02 & 0.829 \\
\hline 5. & Leading effective staff development & 96 & 2.10 & 0.788 \\
\hline 30. & Addressing ELL/bilingual issues & 94 & 2.11 & 0.809 \\
\hline 26. & Implementing district/building policy & 83 & 2.19 & 0.890 \\
\hline 2. & Possessing knowledge of effective instructional methods (best practices) & 97 & 2.20 & 0.671 \\
\hline 24. & Staffing/Interviewing skills & 76 & 2.20 & 0.845 \\
\hline 29. & Managing special education laws/issues & 94 & 2.26 & 0.854 \\
\hline 21. & Overseeing the accreditation process & 84 & 2.36 & 0.914 \\
\hline 9. & Conducting formal evaluations & 83 & 2.40 & 0.855 \\
\hline
\end{tabular}

We notice that the best means scores in terms of the perceived competence for novice male administrative staff appear in question 27: effectively handling individual student discipline issues with an average of 1.54. Then follows question 34: working with parent organizations and/or committees with an average of 1.56 and after that two questions with the same average, that is 1.60 , follow. These are question 7 : improving overall school climate and question 11: learning routine office tasks/procedures, after them question 12: preparing for and conducting effective faculty teacher's meetings is next with an average of 1.61. On the contrary, the worst means scores in terms of the perceived competence for novice male administrative staff are noticed in question 9: conducting formal evaluations with an average of 2.40, followed by question 21: supervision of the assessment-certification process and question 29: managing special education laws/issues with averages of 2.36 and 2.26 respectively.

Table 2 below includes all the data of the administrative staff deriving from the "Principal's Perception of Competence Survey" questionnaire with a classification from the best to the worst, based on the means scores of the perceived competence for novice female administrative staff $(\mathrm{N}=83)$. The number of respondents to this survey varies per question-itemcompetence. The averages were based on the values: $1=$ fully competent, $2=$ somehow competent, $3=$ =marginally competent $4=$ not competent, as the answer $5=$ have never experienced was excluded from the analysis.

we notice that the best means scores of the perceived competence for novice female administrative staff are shown in question 27: effectively handling individual student discipline issues with an average of 1.63. Then follow question 36: dealing with concerned/angry parents with an average of 1.65 , question 34: working with parent organizations and/or committees with an average of 1.66 , and after that two questions with the same average, that is 1.78. these are question 7: improving overall school climate and question 8: improving staff morale. On the contrary, the worst means scores in terms of perceived competence for novice female administrative staff appear in question 9: conducting formal evaluations with an average of 2.61, followed by question 24 : staffing/interviewing skills and question 26: implementing district/building policy with averages of 2.43 and 2.39 respectively. 
Table 2: Perceived competence means scores (ms) and standard deviations (sd) for novice female administrative staff (principals and vice-principals)

(up to 3 years of administrative experience)

\begin{tabular}{|c|c|c|c|c|}
\hline \multicolumn{2}{|r|}{ Question-item-competence } & $\mathbf{N}$ & MS & SD \\
\hline 27. & Effectively handling individual student discipline issues & 82 & 1.63 & 0.619 \\
\hline 36. & Dealing with concerned/angry parents & 83 & 1.65 & 0.614 \\
\hline 34. & Working with parent organizations and/or committees & 80 & 1.66 & 0.655 \\
\hline 7. & Improving overall school climate & 83 & 1.78 & 0.663 \\
\hline 8. & Improving staff morale & 80 & 1.78 & 0.636 \\
\hline 37. & Developing decision-making skills & 81 & 1.79 & 0.666 \\
\hline 39. & Possessing mediation skills (staff vs. staff and/or student vs. student) & 81 & 1.81 & 0.673 \\
\hline 35. & Organising and supervising school activities/athletics & 77 & 1.81 & 0.689 \\
\hline 12. & Preparing for and conducting effective faculty meetings & 80 & 1.84 & 0.719 \\
\hline 38. & Developing time management skills & 82 & 1.88 & 0.710 \\
\hline 31. & Developing public relations skills & 80 & 1.89 & 0.779 \\
\hline 28. & Interpreting and enforcing school law issues & 81 & 1.90 & 0.752 \\
\hline 4. & Assisting teachers in creating more effective lesson plans & 80 & 1.90 & 0.756 \\
\hline 20. & Leading curriculum development & 77 & 1.96 & 0.751 \\
\hline 10. & Supervising staff & 81 & 1.96 & 0.660 \\
\hline 40. & Possessing necessary technology skills & 83 & 1.99 & 0.672 \\
\hline 18. & Guiding the school improvement process & 81 & 1.99 & 0.750 \\
\hline 19. & Analysing student data & 82 & 2.00 & 0.786 \\
\hline 32. & Possessing public speaking skills & 80 & 2.00 & 0.827 \\
\hline 15. & Addressing custodial staff issues & 81 & 2.01 & 0.766 \\
\hline 33. & Creating an effective site council & 78 & 2.01 & 0.747 \\
\hline 6. & Creating an atmosphere of high expectations & 81 & 2.01 & 0.661 \\
\hline 17. & Addressing secretarial staff issues & 72 & 2.04 & 0.813 \\
\hline 41. & Developing and preparing for board meeting presentations & 72 & 2.04 & 0.740 \\
\hline 11. & Learning routine office tasks/procedures & 81 & 2.05 & 0.805 \\
\hline 3. & Instructing teachers in effective instructional techniques & 79 & 2.05 & 0.799 \\
\hline 30. & Addressing ELL/bilingual issues & 78 & 2.05 & 0.788 \\
\hline 5. & Leading effective staff development & 80 & 2.09 & 0.750 \\
\hline 13. & Teacher union issues & 76 & 2.14 & 0.795 \\
\hline 14. & Addressing building maintenance issues & 75 & 2.15 & 0.911 \\
\hline 2. & Possessing knowledge of effective instructional methods (best practices) & 76 & 2.16 & 0.731 \\
\hline 1. & Possessing instructional leadership skills & 76 & 2.17 & 0.681 \\
\hline 29. & Managing special education laws/issues & 77 & 2.18 & 0.869 \\
\hline 25. & Dealing with the building budget & 75 & 2.21 & 0.890 \\
\hline 22. & Completing education reports & 76 & 2.21 & 0.914 \\
\hline 16. & Addressing fire marshal issues & 74 & 2.28 & 0.852 \\
\hline 23. & Handling site-based management & 74 & 2.28 & 0.914 \\
\hline 21. & Overseeing the accreditation process & 64 & 2.36 & 0.932 \\
\hline 26. & Implementing district/building policy & 66 & 2.39 & 0.975 \\
\hline 24. & Staffing/Interviewing skills & 67 & 2.43 & 0.925 \\
\hline 9. & Conducting formal evaluations & 66 & 2.61 & 0.943 \\
\hline
\end{tabular}

Table 3 above includes all the data of the administrative staff deriving from the 'Principal's Perception of Competence Survey' questionnaire ranking from the best to the worst, based on the means scores of the perceived competence for experienced male administrative staff $(\mathrm{N}=175)$. The number of respondents to this survey varies per question-itemcompetence. The averages were based on the values: $1=$ fully competent, $2=$ somehow competent, $3=$ marginally competent, $4=$ not competent, as the answer $5=$ have never experienced was excluded from the analysis.

It is noticed that the best means scores in terms of the perceived competence for experienced male administrative staff appear in question 34: working with parent organizations and/or committees with an average of 1.35. then follows question 7: improving overall school climate with an average of 1.38 , and after that with the same average, that is 1.42 , two other questions follow which are question 11: learning routine office tasks/procedures and question 37: developing decisionmaking skills. After them question 12: preparing for and conducting effective faculty teacher's meetings follows with an average of 1.43. On the contrary, the worst means scores in terms of the perceived competence for experienced male administrative staff appear once again in question 9: conducting formal evaluations with an average of 2.40 , followed by question 24: staffing/interviewing skills and question 21: overseeing the accreditation process with averages of 2.21 and 2.13 respectively.

Table 3: Perceived competence means scores (ms) and standard deviations (sd) for experienced male administrative staff (principals and vice-principals)

(more than 3 years of administrative experience)

\begin{tabular}{|c|l|c|c|c|}
\hline \multicolumn{1}{|c|}{ Question-item-competence } & N & MS & SD \\
\hline 34. & Working with parent organizations and/or committees & 173 & 1.35 & 0.513 \\
\hline 7. & Improving overall school climate & 173 & 1.38 & 0.522 \\
\hline 11. & Learning routine office tasks/procedures & 171 & 1.42 & 0.518 \\
\hline 37. & Developing decision-making skills & 174 & 1.42 & 0.550 \\
\hline
\end{tabular}


Innovare Journal of Education, Vol 9, Issue 2, 2021, 9-17

\begin{tabular}{|c|c|c|c|c|}
\hline \multicolumn{2}{|r|}{ Question-item-competence } & $\mathbf{N}$ & MS & SD \\
\hline 12. & Preparing for and conducting effective faculty meetings & 172 & 1.43 & 0.631 \\
\hline 15. & Addressing custodial staff issues & 171 & 1.44 & 0.595 \\
\hline 28. & Interpreting and enforcing school law issues & 174 & 1.44 & 0.584 \\
\hline 8. & Improving staff morale & 173 & 1.45 & 0.604 \\
\hline 27. & Effectively handling individual student discipline issues & 173 & 1.46 & 0.555 \\
\hline 25. & Dealing with the building budget & 169 & 1.47 & 0.716 \\
\hline 36. & Dealing with concerned/angry parents & 174 & 1.47 & 0.545 \\
\hline 39. & Possessing mediation skills (staff vs. staff and/or student vs. student) & 171 & 1.47 & 0.587 \\
\hline 14. & Addressing building maintenance issues & 171 & 1.48 & 0.636 \\
\hline 18. & Guiding the school improvement process & 173 & 1.53 & 0.596 \\
\hline 35. & Organising and supervising school activities/athletics & 172 & 1.55 & 0.669 \\
\hline 10. & Supervising staff & 170 & 1.63 & 0.720 \\
\hline 22. & Completing education reports & 167 & 1.63 & 0.748 \\
\hline 33. & Creating an effective site council & 167 & 1.64 & 0.623 \\
\hline 38. & Developing time management skills & 174 & 1.64 & 0.655 \\
\hline 17. & Addressing secretarial staff issues & 156 & 1.65 & 0.669 \\
\hline 31. & Developing public relations skills & 173 & 1.65 & 0.713 \\
\hline 13. & Teacher union issues & 175 & 1.67 & 0.782 \\
\hline 19. & Analysing student data & 170 & 1.68 & 0.710 \\
\hline 6. & Creating an atmosphere of high expectations & 172 & 1.69 & 0.634 \\
\hline 32. & Possessing public speaking skills & 174 & 1.70 & 0.740 \\
\hline 40. & Possessing necessary technology skills & 174 & 1.71 & 0.645 \\
\hline 16. & Addressing fire marshal issues & 170 & 1.72 & 0.777 \\
\hline 1. & Possessing instructional leadership skills & 174 & 1.73 & 0.550 \\
\hline 20. & Leading curriculum development & 173 & 1.75 & 0.735 \\
\hline 41. & Developing and preparing for board meeting Presentations & 167 & 1.79 & 0.820 \\
\hline 23. & Handling site-based management & 162 & 1.85 & 0.846 \\
\hline 30. & Addressing ELL/bilingual issues & 167 & 1.85 & 0.758 \\
\hline 2. & Possessing knowledge of effective instructional methods (best practices) & 172 & 1.87 & 0.621 \\
\hline 5. & Leading effective staff development & 174 & 1.87 & 0.795 \\
\hline 4. & Assisting teachers in creating more effective lesson plans & 172 & 1.91 & 0.764 \\
\hline 29. & Managing special education laws/issues & 170 & 1.91 & 0.813 \\
\hline 3. & Instructing teachers in effective instructional techniques & 168 & 1.95 & 0.699 \\
\hline 26. & Implementing district/building policy & 153 & 1.99 & 0.851 \\
\hline 21. & Overseeing the accreditation process & 149 & 2.13 & 0.816 \\
\hline 24. & Staffing/Interviewing skills & 141 & 2.21 & 0.883 \\
\hline 9. & Conducting formal evaluations & 149 & 2.40 & 0.788 \\
\hline
\end{tabular}

Table 4 below includes all the data of the administrative staff deriving from the 'Principal's Perception of Competence Survey' questionnaire ranking from the best to the worst, based on the means scores of the perceived competence for experienced female administrative staff $(\mathrm{N}=55)$. The number of respondents to this survey varies per question-itemcompetence. The averages were based on the values: 1=fully competent, $2=$ somehow competent, $3=$ marginally competent, $4=$ not competent, as the answer $5=$ have never experienced was excluded from the analysis.

Table 4: Perceived competence means scores (ms) and standard deviations (sd) for experienced female administrative staff (principals and vice-principals)

(more than 3 years of administrative experience)

\begin{tabular}{|c|c|c|c|c|}
\hline \multicolumn{2}{|r|}{ Question-item-competence } & \multirow{2}{*}{$\begin{array}{c}\mathbf{N} \\
55 \\
\end{array}$} & \multirow{2}{*}{$\begin{array}{c}\text { MS } \\
1.38 \\
\end{array}$} & \multirow{2}{*}{$\frac{\text { SD }}{0.527}$} \\
\hline 7. & Improving overall school climate & & & \\
\hline 39. & Possessing mediation skills (staff vs. staff and/or student vs. student) & 53 & 1.40 & 0.531 \\
\hline 8. & Improving staff morale & 55 & 1.45 & 0.662 \\
\hline 34. & Working with parent organizations and/or committees & 55 & 1.45 & 0.603 \\
\hline 37. & Developing decision-making skills & 55 & 1.51 & 0.690 \\
\hline 10. & Supervising staff & 54 & 1.52 & 0.693 \\
\hline 12. & Preparing for and conducting effective faculty meetings & 52 & 1.52 & 0.804 \\
\hline 25. & Dealing with the building budget & 54 & 1.52 & 0.720 \\
\hline 35. & Organising and supervising school activities/athletics & 55 & 1.53 & 0.663 \\
\hline 11. & Learning routine office tasks/procedures & 54 & 1.54 & 0.693 \\
\hline 27. & Effectively handling individual student discipline issues & 55 & 1.55 & 0.663 \\
\hline 36. & Dealing with concerned/angry parents & 55 & 1.55 & 0.633 \\
\hline 38. & Developing time management skills & 55 & 1.55 & 0.741 \\
\hline 28. & Interpreting and enforcing school law issues & 55 & 1.58 & 0.786 \\
\hline 13. & Teacher union issues & 55 & 1.65 & 0.751 \\
\hline 18. & Guiding the school improvement process & 55 & 1.67 & 0.640 \\
\hline 31. & Developing public relations skills & 54 & 1.67 & 0.824 \\
\hline 40. & Possessing necessary technology skills & 55 & 1.69 & 0.573 \\
\hline 17. & Addressing secretarial staff issues & 54 & 1.70 & 0.690 \\
\hline 32. & Possessing public speaking skills & 53 & 1.70 & 0.696 \\
\hline
\end{tabular}


Innovare Journal of Education, Vol 9, Issue 2, 2021, 9-17

\begin{tabular}{|c|c|c|c|c|}
\hline \multicolumn{2}{|r|}{ Question-item-competence } & $\mathbf{N}$ & MS & SD \\
\hline 33. & Creating an effective site council & 54 & 1.70 & 0.816 \\
\hline 19. & Analysing student data & 53 & 1.72 & 0.744 \\
\hline 14. & Addressing building maintenance issues & 55 & 1.73 & 0.732 \\
\hline 20. & Leading curriculum development & 51 & 1.73 & 0.750 \\
\hline 15. & Addressing custodial staff issues & 55 & 1.75 & 0.726 \\
\hline 6. & Creating an atmosphere of high expectations & 52 & 1.79 & 0.696 \\
\hline 1. & Possessing instructional leadership skills & 55 & 1.82 & 0.611 \\
\hline 4. & Assisting teachers in creating more effective lesson plans & 55 & 1.82 & 0.772 \\
\hline 22. & Completing education reports & 53 & 1.83 & 0.893 \\
\hline 29. & Managing special education laws/issues & 52 & 1.87 & 0.817 \\
\hline 2. & Possessing knowledge of effective instructional methods (best practices) & 53 & 1.89 & 0.870 \\
\hline 3. & Instructing teachers in effective instructional techniques & 55 & 1.89 & 0.685 \\
\hline 30. & Addressing ELL/bilingual issues & 53 & 1.89 & 0.776 \\
\hline 23. & Handling site-based management & 48 & 1.90 & 0.857 \\
\hline 41. & Developing and preparing for board meeting presentations & 52 & 1.90 & 0.799 \\
\hline 26. & Implementing district/building policy & 47 & 1.91 & 0.905 \\
\hline 16. & Addressing fire marshal issues & 53 & 1.92 & 0.851 \\
\hline 5. & Leading effective staff development & 52 & 1.94 & 0.752 \\
\hline 24. & Staffing/Interviewing skills & 45 & 2.00 & 0.853 \\
\hline 21. & Overseeing the accreditation process & 46 & 2.15 & 0.816 \\
\hline 9. & Conducting formal evaluations & 42 & 2.17 & 0.961 \\
\hline
\end{tabular}

We notice that the best means scores for the perceived competence for experienced female administrative staff are shown in question 7: improving overall school climate with an average of 1.38. question 39: possessing mediation skills (staff vs. staff and/or student vs. student) follows with an average of 1.40 and after that with the same average, that is 1.45 , two other questions follow which are question 8: improving staff morale and question 34: working with parent organizations and/or committees. After them question 37: developing decision-making skills follows with an average of 1.51. On the contrary, the worst means scores in terms of the perceived competence for experienced female administrative staff reappear in question 9: conducting formal evaluations with an average of 2.17, followed by question 21: overseeing the accreditation process and question 24: staffing/interviewing skills with averages of 2.15 and 2.00 respectively.

In general, the average perceived competence of male administrative staff is better than that of female in 40 of the 41 questions with an exception only in question 4: assisting teachers in creating more effective lesson plans. Therefore, the overall average perceived competence of male administrative staff is quite better than that of female ones (average $=1.75 \mathrm{vs}$. average $=1.89$ ). This specific difference concerning the average perceived competence is also proportional to the individual comparisons between both experienced and inexperienced male administrative staff (average $=1.69$ vs. average $=1.87$ ), as well as between experienced and inexperienced female administrative staff (average $=1.70$ vs. average=2.01). In particular, the averages of perceived competence between experienced and inexperienced male administrative staff appear to be equal in question 9: formal evaluations with an average of 2.40, while questions 24: staffing/interviewing skills and 40: possessing necessary technology skills are the only ones in which the average competence of novice male administrative staff is better than that of the experienced ones ( with average $=2.20 \mathrm{vs}$. average $=2.21$ and with average $=1.64 \mathrm{vs}$. average $=1.71$ respectively). In all other questions, the average competence of experienced male administrative staff is better than that of the inexperienced ones ranging from 0.03 (question 4: help teachers create more effective lesson plans with average $=1.91$ vs. average $=1.94$ ) to 0.37 (question 15: addressing custodial staff issues with average=1.44 vs average=1.81). As far as female administrative staff is concerned, the average perceived competence for experienced female administrative staff is better than that of the inexperienced ones in all 41 questions with a difference ranging from 0.08 (question 4: help teachers create more effective lesson plans with average $=1.82$ vs. average $=1.90$ ) to 0.69 (question 25: school unit budget management with average $=1.52$ vs. average $=2.21$ ). If we focus on the need for training of the administrative staff, as far as the perceived averages of competence for novice male administrative staff are concerned, the data revealed that 9 out of the 41 averages for administrative competencies fell below 2.0. It means that the specific administrative staff of the prefecture of Thessaloniki does not feel particularly competent in terms of their specific administrative responsibilities. These nine items are listed in table 5 below. There are issues for which this category of administrative staff has never undergone any university education in the past.

Table 5: Competence means scores falling below 2.0 for novice male administrative staff

\begin{tabular}{|c|l|c|}
\hline \multicolumn{1}{|c|}{ Question-item-competence } & Means scores & \\
\hline 23. & Handling bite-based management & 2.02 \\
\hline 5. & Leading effective staff development & 2.10 \\
\hline 30. & Addressing ELL/bilingual issues & \\
\hline 26. & Implementing district/building policy & 2.11 \\
\hline 2. & Possessing knowledge of effective instructional methods (best practices) & \\
\hline 24. & Staffing/Interviewing skills & 2.19 \\
\hline 29. & Managing special education laws/issue & 2.20 \\
\hline 21. & Overseeing the accreditation process & 2.20 \\
\hline 9. & Conducting formal evaluations & 2,26 \\
\hline
\end{tabular}

Focusing on the need for training of the administrative staff, as far as the perceived averages of competence for novice female administrative staff are concerned, the data revealed that 22 of the 41 means scores for administrative competences fell below 2.0. It means that the specific administrative staff of the prefecture of Thessaloniki does not feel particularly competent in terms of their specific administrative responsibilities. These twenty-two items are listed in table 6 below. Once more, there are still issues for which this category of administrative staff has never undergone any university education in the past. 
Table 6: Competence means scores falling below 2.0 for novice female administrative staff

\begin{tabular}{|c|l|c|}
\hline \multicolumn{1}{|c|}{ Question-item-competence } & Means scores \\
\hline 15. & Addressing custodial staff issues & 2.01 \\
\hline 33. & Creating an effective site council & 2.01 \\
\hline 6. & Creating an atmosphere of high expectations & 2.01 \\
\hline 17. & Addressing secretarial staff issues & 2.04 \\
\hline 41. & Developing and preparing for board meeting presentations & 2.04 \\
\hline 11. & Learning routine office tasks/procedures & 2.05 \\
\hline 3. & Instructing teachers in effective instructional techniques & 2,05 \\
\hline 30. & Addressing ELL/bilingual issues & 2.05 \\
\hline 5. & Leading effective staff development & 2.09 \\
\hline 13. & Teacher union issues & 2.14 \\
\hline 14. & Addressing building maintenance issues & 2.15 \\
\hline 2. & Possessing knowledge of effective instructional methods (best practices) & 2.16 \\
\hline 1. & Possessing instructional leadership skills & 2.17 \\
\hline 29. & Managing special education laws/issues & 2.18 \\
\hline 25. & Dealing with the building budget & 2.21 \\
\hline 22. & Completing education reports & 2.21 \\
\hline 16. & Addressing fire marshal issues & 2.28 \\
\hline 23. & Handling site-based management & 2.28 \\
\hline 21. & Overseeing the accreditation process & 2.36 \\
\hline 26. & Implementing district/building policy & 2.39 \\
\hline 24. & Staffing/Interviewing skills & 2,43 \\
\hline 9. & Conducting formal evaluations & 2.61 \\
\hline
\end{tabular}

If we focus on the need for training of the administrative staff, as far as the perceived averages of competence for experienced male administrative staff are concerned, the data revealed that only 3 of the 41 means scores for administrative competences fell below 2.0. It means that these administrative staff of the prefecture of Thessaloniki does not feel particularly competent in terms of their specific administrative responsibilities. These three items are listed in table 7 below. There are issues again for category of administrative staff who had never undergone any university education in the past. Focusing on the need for training of the administrative staff, as far as the perceived averages of competence for experienced female administrative staff are concerned, the data revealed that only 2 of the 41 means scores for administrative competences fell below 2.0. It means that the specific administrative staff of the prefecture of Thessaloniki does not feel particularly competent in terms of their specific administrative responsibilities. These two items are listed in table 8 below. There are issues for which this category of administrative staff has never undergone any university education in the past.

Table 7: Competence means scores falling below 2.0 for experienced male administrative staff

\begin{tabular}{|c|l|c|}
\hline \multicolumn{1}{|c|}{ Question-item-competence } & Means scores \\
\hline 21. & Overseeing the accreditation process & 2.13 \\
\hline 24. & Staffing/Interviewing skills & 2.21 \\
\hline 9. & Conducting formal evaluations & 2.40 \\
\hline
\end{tabular}

Table 8: Competence means scores falling below 2.0 for experienced female administrative staff

\begin{tabular}{|c|l|c|}
\hline \multicolumn{1}{|c|}{ Question-item-competence } & Means scores \\
\hline 21. & Overseeing the accreditation process & 2.15 \\
\hline 9. & Conducting formal evaluations & 2.17 \\
\hline
\end{tabular}

To conclude, taking into consideration the individual tables concerning the correlation between the experience with the gender, it is useful to present a brief comparative table 9 in which the best and worst means scores are listed per question in order to make the findings of the research more understandable.

Table 9: The best and the worst competence means scores concerning the correlation between experience and gender

\begin{tabular}{|c|l|l|l|}
\hline \multicolumn{2}{|c|}{ Question-item-competence } & \multicolumn{1}{c|}{ Best group } & Worst group \\
\hline 1. & Possessing instructional leadership skills & Experienced male & Novice female \\
\hline 2. & $\begin{array}{l}\text { Possessing knowledge of effective instructional methods } \\
\text { (best practices) }\end{array}$ & Experienced male & Novice male \\
\hline 3. & Instructing teachers in effective instructional techniques & Experienced female & Novice female \\
\hline 4. & Assisting teachers in creating more effective lesson plans & Experienced female & Novice male \\
\hline 5. & Leading effective staff development & Experienced male & Novice male \\
\hline 6. & Creating an atmosphere of high expectations & Experienced male & Novice female \\
\hline 7. & Improving overall school climate & $\begin{array}{l}\text { Experienced male Experienced } \\
\text { female }\end{array}$ & Novice female \\
\hline 8. & Improving staff morale & $\begin{array}{l}\text { Experienced male Experienced } \\
\text { female }\end{array}$ & Novice female \\
\hline 9. & Conducting formal evaluations & Experienced female & Novice female \\
\hline 10. & Supervising staff & Experienced female & Novice female \\
\hline 11. & Learning routine office tasks/procedures & Experienced male & Novice female \\
\hline
\end{tabular}


Innovare Journal of Education, Vol 9, Issue 2, 2021, 9-17

\begin{tabular}{|c|c|c|c|}
\hline \multicolumn{2}{|r|}{ Question-item-competence } & Best group & Worst group \\
\hline 12. & Preparing for and conducting effective faculty meetings & Experienced male & Novice female \\
\hline 13. & Teacher union issues & Experienced female & Novice female \\
\hline 14. & Addressing building maintenance Issues & Experienced male & Novice female \\
\hline 15. & Addressing custodial staff issues & Experienced male & Novice female \\
\hline 16. & Addressing fire marshal issues & Experienced male & Novice female \\
\hline 17. & Addressing secretarial staff issues & Experienced male & Novice female \\
\hline 18. & Guiding the school improvement process & Experienced male & Novice female \\
\hline 19. & Analysing student data & Experienced male & Novice female \\
\hline 20. & Leading curriculum development & Experienced female & Novice female \\
\hline 21. & Overseeing the accreditation process & Experienced male & Novice male Novice female \\
\hline 22. & Completing education reports & Experienced male & Novice female \\
\hline 23. & Handling site-based management & Experienced male & Novice female \\
\hline 24. & Staffing/Interviewing skills & Experienced female & Novice female \\
\hline 25. & Dealing with the building budget & Experienced male & Novice female \\
\hline 26. & Implementing district/building policy & Experienced female & Novice female \\
\hline 27. & Effectively handling individual student discipline issues & Experienced male & Novice female \\
\hline 28. & Interpreting and enforcing school law issues & Experienced male & Novice female \\
\hline 29. & Managing special education laws/issues & Experienced female & Novice male \\
\hline 30. & Addressing ELL/bilingual issues & Experienced male & Novice male \\
\hline 31. & Developing public relations skills & Experienced male & Novice female \\
\hline 32. & Possessing public speaking skills & $\begin{array}{l}\text { Experienced male Experienced } \\
\text { female }\end{array}$ & Novice female \\
\hline 33. & Creating an effective site council & Experienced male & Novice female \\
\hline 34. & Working with parent organizations and/or committees & Experienced male & Novice female \\
\hline 35. & Organising and supervising school activities/athletics & Experienced female & Novice female \\
\hline 36. & Dealing with concerned/angry parents & Experienced male & Novice female \\
\hline 37. & Developing decision-making skills & Experienced male & Novice female \\
\hline 38. & Developing time management skills & Experienced female & Novice female \\
\hline 39. & $\begin{array}{l}\text { Possessing mediation skills (staff vs. staff and/or student } \\
\text { vs. student) }\end{array}$ & Experienced female & Novice female \\
\hline 40. & Possessing necessary technology skills & Novice male & Novice female \\
\hline 41. & $\begin{array}{l}\text { Developing and preparing for board meeting } \\
\text { presentations }\end{array}$ & Experienced male & Novice female \\
\hline
\end{tabular}

We notice that as far as the experience-gender relation is concerned, in almost half of the questions, that is in 21 out of the 41 , the experienced male administrative staff show the best percentages and the novice female the worst. There are also 11 questions in which experienced female administrative staff show the best results and novice the worst. All other questions reveal completely different results, with either partial or absolute differentiation. More specifically, there are 2 questions in which experienced female administrative staff shows the best results and novice female the worst, 2 questions in which experienced female show the best percentages and novice male the worst, 3 questions in which experienced male and experienced female are equal to the best percentages, as well as 1 question in which the percentages of the novice male are equal to the worst percentages of the novice female ones. Finally, there 1 question in which novice male administrative staff show the best perceived competence of all the others.

\section{DISCUSSION}

It is clearly understood that managers should become experts in studying their environment, determining which clues are the most important, and what the most appropriate management role to use in response to each clue is. Additionally, there will be a need that they own a wide range of competence on which to lean so that they meet their constantly changing requirements environment (Vilkinas \& Cartan, 1993). It is also worth mentioning that in the majority of cases, the school principal remains a teacher. To meet the responsibilities he/she takes on, he/she must possess a lot of organizational competencies, be highly motivated, creative and ready to cooperate (Dyrda \& Pryzbylska, 2008). Based on the findings of this particular research concerning experience-gender correlation, it is understood that our predictions were confirmed. In particular, it was revealed that the novice primary school administrative staff need more training than the experienced ones and also that male primary school administrative staff needs less training than the female ones. In addition, it was noticed that the greatest need for training seems to concern the novice female administrative staff, while on the contrary, the least need for training concerns the experienced male ones. Training programme designers should take the aforementioned very seriously when creating a training or mentoring courses emphasising mostly on aspiring principals and vice-principals.

\section{CONCLUSION}

In general, the above findings are reasonable because both the given inadequacy of university education and the absence of training provision that accompanies the entire working career of school teachers in Greece. The existing deficiencies of the administrative staff in these particular forty-one competences, as expressed by themselves in this research, could direct education policymakers in Greece to turn their point of interest into the training of the administrative staff in general and especially that of the novice ones, focusing on specific areas of competences concerning school administration. In this way, all the appropriate conditions will be prepared and cultivated so that people who lead schools, as well as the aspiring ones, will be capable of performing their administrative duties efficiently and effectively, providing in this way the impetus for the achievement of the best possible learning outcomes on the student's part.

\section{ACKNOWLEDGEMENT}

I am indebted to Kelly Glodt, who gave me his permission to use his questionnaire and the Ministry of Education in Greece that approved my application form to conduct the research. I also express our sincerest gratitude to all the principals and vice-principals of the prefecture of Thessaloniki in Greece who participated willingly in this study. 


\section{AUTHORS CONTRIBUTIONS}

The author is responsible for the introduction, the reviews of related literature, the data gathering, the methodology, the discussions and the conclusions, as well as the proofreading.

\section{CONFLICT OF INTEREST}

The author declares that he has no sort of conflict of interest with anyone or anything.

\section{REFERENCES}

- Cheng, Y. C. (2005). New paradigm for re-engineering education: Globalization, localization and individualization. Dordrecht, Netherlands: Springer doi.org/10.1007/1-4020-3620-5

- $\quad$ Davies, B., \& Ellison, L. (1997). School leadership for the 21st century: A competency and knowledge approach (1st ed.). London, England and New York, USA: Routledge Falmer.

- $\quad$ Deal, T., \& Peterson, K. (2010). Shaping school culture: The heart of leadership (1st ed.). San Francisco, USA: JosseyBass.

- Derek, E. (2013). Competences for school managers. London, Philadelphia: Kogan Page Limited.

- Dipaola, M., \& Forsyth, P. (2011). Leading research in educational administration: A festschrift for Wayne K. Hoy. Charlotte, North Carolina, USA: Information Age Publishing.
- Dyrda, B., \& Przybylska, I. (2008). Dimensions of the role of the head teacher in the educational system in Poland. The New Educational Review, 16(3/4), 127-135.

- Foot, M., \& Hook, C. (2008). Introducing human resource management (5th ed.). Australia: Prentice Hall.

- McAndrew, D. (2005). Literacy leadership: Six strategies for people work. Indiana, USA: International Reading Association.

- Petroselli, C. (2008). Science education issues and developments. New York, USA: Nova Science Pub Inc.

- $\quad$ Robotham, D., \& Jubb, R. (1996). Competences: Measuring the unmeasurable. Management Development Review, 9(5), 25-29. doi.org/10.1108/09622519610131545

- Vilkinas, T., \& Cartan, G. (1993). Competences of Australian women in management. Women in Management Review, 8(3), 31-35. doi.org/10.1108/09649429310037652

- Wilburn, K., \& Summers, I. (1983). The continuing education of administrators: Identifying competences, the critical first step. Paper presented at the Annual Meeting of the American Education Research Association (pp. 1-35). New Orleans: LA, USA, 23-27 April 1984.

- Wilson, J. (2005). Human resource development: Learning \& training for individuals and organizations (2nd ed.) London, England: Kogan Page.

- Winterton, J., \& Winterton, R. (1999). Developing managerial confidence (1st ed.). London, England: Routledge.

- Zuzelo, P. R. (2010). The clinical nurse specialist handbook (2nd ed.). Sudbury, Massachusetts, USA: Jones and Bartlett. 